\title{
Perception of School Heads on Teachers' Professionalism and Pupils' Behavior as Determinants of Academic Achievement among Primary Schools in Central Nyanza, Kenya
}

\author{
Daniel Oduor Onyango, PhD \\ Department of Education Foundations, St. Augustine University of Tanzania \\ Corresponding Author: d.juma@yahoo.com
}

\begin{abstract}
The purpose of this study was to establish the perception of school heads on teachers' professionalism and pupils' behavior as determinants for academic achievement among primary schools in Central Nyanza Region, Kenya. The study employed the descriptive survey design. The population of the study consisted of heads of 1356 primary schools in the counties of Kisumu and Siaya which are found in Central Nyanza Region of Kenya. Stratified random sampling was used to select a sample of 136 heads of schools from the two counties which was $10 \%$ of the population. The instruments used to collect data were a questionnaire and an interview guide. Descriptive statistics in terms of means and standard deviations were used to analyze the quantitative data while the thematic approach was used to analyze qualitative data. The study concluded that teachers' professionalism and pupils' behaviors such as absenteeism and negative attitude towards the curriculum content contributed to poor academic achievement among the primary schools. The study recommended that teachers need to maintain high professional standards as they carry out their responsibilities. Likewise parents and teachers should help learners to develop positive attitude towards the curriculum content and attend school regularly.
\end{abstract}

Keywords: Influence, Teachers, Pupils, Behavior, Primary Schools, Academic Performance, Central Nyanza Region, Kenya

\section{Introduction}

Poor achievement in Certificate of Primary Education Examination in Kenya continues to be a vital concern to the parents, teachers, educational authorities and pupils. While there are various factors which may influence academic achievement, there was need to find out how teachers' professionalism and pupils' behavior influence the academic achievement in Kenyan Primary Schools. The study was guided by two research questions: (1) what is the perception of school heads on teachers' professionalism as a determinant for academic achievement among primary schools in Central Nyanza? (2) What is the perception of school heads on pupils' behavior as a determinant for academic achievement among primary schools in Central Nyanza? The researcher went through a range of literature to explore more about teachers' professionalism and pupils' behavior as determinants of academic achievement.

\section{Teachers' Professionalism}

With regard to teachers' professionalism, Huitt (1994) observed that whatever happens in class and out of class between the teacher and the learners contribute significantly to learners' academic achievement. According to Farrant (2007), professionalism is the key to sustained good performance by teachers. While teachers need to be catalysts for students' academic achievement, this will only be possible if they create a productive climate for learning, employ pupils' ideas in learning and explain facts clearly. They also need to select appropriate methods that stimulate cognitive development, utilize teaching materials effectively and encourage learning by doing. Farrant (2007) further notes that teachers should encourage pupils 
to work hard and love their work for maximized academic achievement.

Kibera and Kimokoti (2007) have shown that teachers' expectations can influence academic achievement in primary schools. They further argue that a good relationship between teachers and learners leads to maximized academic achievement. Ornestein and Hunkins (1998) posit that through effective teaching, a lot of changes can take place in the society when the school releases to the world learners who have received quality education. The learners would then spur technological development in the country and beyond for the good of society. On the contrary, Primary School teachers in Kenya have been blamed for using teaching methods which are not appropriate for the primary school level (Oduor, 2011). The methods used are geared to preparing pupils to pass the Kenya Certificate of Primary Examinations They often promote learner passivity and fail to bring about effective learning. Therefore, there is need to employ appropriate teaching methods which will enhance creativity and independent thinking among the learners (Arends, 2011).

The Kenya Institute of Education (2010) has reported that the implementation of the syllabus is failing because too much emphasis is being placed on theory rather than practice. The teachers do not use teaching and learning experiences which would make the curriculum relevant to the learners. The Ministry of Education, Science and Technology (2003) report on education sector indicates that while parents in Kenya desire that their children should pass KCPE examinations and proceed to secondary schools which admit the best performing pupils in KCPE, this desire cannot be fulfilled unless teachers play their part through teaching effectively.

A study conducted by UNESCO (2005) in Kenya observed that the standards of learning in Primary schools have gone down due to unplanned practices which have interfered with required standards. The report further identified the following challenges: lack of appropriate learning materials, lack of gender sensitivity and lack of teacher supervision.

According to Kasuni (2011), teachers should make sacrifices to enable the students to succeed. They should endeavor to put in extra efforts even if there are limited incentives. According to Mulkeen and Chen (2008), on the other hand, the school heads should identify and address system challenges such as late salaries and delays in effecting promotions which demotivate teachers. This is because teachers who are not tolerant enough may not take it lightly when salaries and other motivating factors are low.

Wardlaw (2008) argues that the most important function of a school is to provide effective teaching and learning. While curriculum is a vehicle through which the society aims to achieve its aspirations, teachers must be engaged in effective teaching if the goals have to be realized by the society. The author further underscores the fact that the quality of education system cannot exceed the quality of teaching that takes place in the school system. Therefore, teachers need to enhance the quality of their delivery for maximized learning outcomes.

Ayiro (2011) introduced a new dimension into the teaching/learning process by arguing that the $21^{\text {st }}$ century teachers should adopt modern techniques of teaching which maximize the learning effectiveness. He advises that in order for this objective to be realized, training institutions should produce teachers who are able to stimulate effective learning and present sound knowledge of what children should learn.

Wiles and Bondi (2011) posit that the role of a supervisor is to enhance teaching and learning; therefore the supervisory practices should empower teachers to engage in effective teaching that is multi-dimensional. The supervisors therefore need to ensure that the teaching/learning process leads to desired effect that is aimed at change in children's behavior.

Arends (2011) further contend that teaching has not been effective because teachers do not allow the learners to take charge of their learning through personal application of the information. They highlight the fact that this occurs because teachers mostly focus on low level objectives at the expense of higher level objectives of learning. As a result, emphasis on low level objectives does not give learners capacity to engage in independent thinking.

Abagi and Odipo (1997) assert that primary school teachers contribute to poor academic achievement by having negative attitude towards their work. This experience causes pupils' absenteeism and therefore poor performance. These findings are relevant to this study as they shed light on how teachers influence the academic achievement. Similarly, Goyal (2007) indicates that lack of teachers' effectiveness is a major cause of poor achievement. He reports the fact that public 
schools in India had well trained, experienced and well paid teachers; while private primary schools had inexperienced teachers and poorly paid, yet in terms of performance, public schools were outperformed by their colleagues in private schools. This suggests a possibility for teachers to do their best to enhance pupils' performance despite the limited resources.

Musvosvi (1998) argues that teachers who use learner centered methods get better results as compared to those who use teacher centered methods. Ayiro (2011) further advises that teachers should employ modern techniques of teaching to enhance learning in the classroom and that teachers should provide learners with opportunities to learn consciously. They should also ensure that classroom conditions stimulate and excite learners. He concludes by indicating that a good teacher should have a sound knowledge of what children should learn.

Similarly, Otunga and Nyandusi (2011) are of the view that teachers should use teaching methods which allow learners to take part in learning. They further argue that learning is best when learners take part and teachers need to do everything possible to make learners autonomous. They propose that there is need for teachers to use appropriate learning materials so as to allow the pupils to interact with learning materials so that effective learning may be realized.

UNESCO (2005) notes that one of the factors that has affected teaching and learning in primary schools is the use of methods that do not support effective learning.

According to Tanner and Tanner (1995), teachers should use methods that will contribute to good achievement by pupils. They also indicate that there is a connection between teachers' competencies and schools academic achievement. Therefore, school leaders should invest in production of competent teachers for effective learning to be realized.

Research indicates that teachers' absenteeism is a kay factor that hinders pupils' academic achievement. According to Otieno (2010), for instance, whenever KCPE examinations are released, Nyanza province does not perform well due to the fact that teachers spend much of their time on noncurriculum issues, personal businesses and thus the syllabus is hardly covered as intended. Reche et al.
(2012) further explains that teacher's absenteeism has an effect on teaching/learning time and therefore affects learners' academic achievement. Particularly, they indicate that in Kenyan Primary Schools, KCPE achievement is affected by time wastage mostly done by teachers.

According to Wasanga et al. (2011), there has been an increase in teacher behavior problems which may affect teaching/learning effectiveness in primary schools. They cite some of these problems as late arrivals for work, skipping classes and sexually harassing pupils. According to Oluka and Okurut (2008), time to learn contributes a lot to pupils' academic achievement in that the hours that the school is in session and the time spent in classroom in actual learning determines the achievement of pupils. Therefore, school leaders need to ensure that teachers use their working hours effectively for better academic achievement.

\section{Pupils' Behavior and Academic Achievement}

Apart from teachers' professionalism, pupils' behavior is another important factor that can determine the learners' academic achievement. Aijaz (2002) observes that the learner is the recipient of the combined efforts from teachers and parents toward effective learning. If the learner is not willing to play their part effectively, then effective academic achievement cannot be realized.

When looking at factors that determine performance in Chemistry, Adesoji and Olatunbosun (2008) found out that student variables such as attitude toward learning and background knowledge in learning science are the causes of poor performance in Chemistry. Ornstein and Hunkins (1998) advocate that there is a need to involve pupils in the teaching/learning process since involving them increases their ability to manage themselves and perform socially acceptable behaviors. Similarly, Oduor (2011) contends that learners should always be provided with their progress reports to enable them to work hard toward effective learning.

Like teachers' absenteeism, pupils' absenteeism has negative effects toward learning effectiveness. Therefore, there is need to ensure their regular attendance and removal of any factors that may negatively affect their attendance rates. Therefore, if there is a problem between them, the school and teachers, their attendance may be affected and as a result, their academic achievement is negatively affected (Onyango, 2008). 
Wardlaw (2008) observes that the negative attitude by learners is caused when the curriculum content is not able to meet the expectations of learners. Learners in the $21^{\text {st }}$ century expect to acquire IT skills and lifelong skills to enable them function in the society by utilizing the skills to make their lives better. Whereas Wardlaw looks at how the curriculum affects the attitudes of pupils, Abagi and Odipo (1997) indicate that socialization has the potential to affect academic achievement.

They argue that, pupils should not be pulled out of class to participate in such events like circumcision and burial ceremonies, which are common in the area under investigation, at the expense of learning. They cite the fact that Initiated pupils often have a negative attitude towards schools and some even develop negative attitude towards their teachers.

Pupils' who frequently absent themselves from school tend not to understand concepts which were taught by their teachers during their absence, which affects their performance in national examinations. In particular, when learners are frequently absent, they are likely not to understand what is taught or they may miss out completely very critical aspects of learning (Ubogu, 2004). Learners therefore, need to be in school during class hours. According to Wasanga et al. (2010), while learners' behavior can contribute positively or negatively towards their learning effectiveness, teachers should assist learners with disciplinary issues to change their behaviors in order to maximize their academic achievement.

Orido (2011) explains that one of the ways in which pupils contribute to poor achievement is their involvement in cheating during examinations. He cites a case where examinations results of thousands of pupils were cancelled due to cheating. When Jamah and Otieno (2011) interviewed the top candidates in the $2011 \mathrm{KCPE}$, they discovered that the secrets of their success included hard work and discipline, reliance on God, study routine, life of determination, having life goals and time management. The findings prove the fact that appropriate pupils' behavior can play great deal toward maximized academic achievement of the learners. Therefore, for pupils to excel in academics they need to work hard and behave appropriately.

\section{Research Methodology}

This part presents the methodology that was used in this study. It highlights on such issues like research design, population and sampling, research instruments used and the statistical treatment of data.

\section{Research Design}

The study used descriptive survey design. This design allowed large amounts of data to be collected over a short period of time. The study used questionnaires and interview guides as tools for data collection. The instruments were prepared by the researcher.

\section{Population and Sampling}

The population of the study consisted of heads of 1356 primary schools in the counties of Kisumu and Siaya which are found in Central Nyanza Region of Kenya. Stratified random sampling was used to select a sample of 136 heads of schools from the two counties which was $10 \%$ of the population. This was done to ensure equitable representation of the population in the study.

\section{Statistical Treatment of Data}

The mixed methods approach was used in data analysis. Thematic approach was used to analyze qualitative data which involved a series of steps in organizing the data in categories and themes. The data which was collected through the questionnaire was analysed using descriptive statistics with the help of the Statistical Package for Social Sciences. The following benchmark was used to interpret the mean scores: $4.50-5.0=$ Strongly Agree, 3.50-4.49= Agree, $2.50-3.49=$ Neutral, $1.50-2.49=$ Disagree , 1.00-1.49 = Strongly Disagree.

\section{Ethical considerations}

In carrying out the study, ethical standards were adhered to by seeking authorization from relevant authorities in Kenya such as National Research Council, District Commissioners and District Education Officers before collecting data from each school. Participants were informed about the purpose and the importance of the study to primary education sector in Kenya and were given freedom to participate or not. Anonymity and confidentiality were observed in that the respondents did not disclose their identities.

\section{Results and Discussion}

This part presents the results of the study and gives the discussion of findings.

\section{Teachers' Professionalism}

The first objective of the study sought to establish the views of school heads on the teachers' professionalism as a determinant for academic 
achievement among primary schools in Central Nyanza. The heads of schools as individuals who supervise teachers were in an excellent position to provide this information. The results are presented in the Table 1 . The results in Table 1 show that the mean scores for the following items ranged between 4.50 and 5.0 and therefore were strongly agreed by the heads of schools: Good teacherstudent relationship affects performance; teachers' prolonged absenteeism affects pupils' achievement and teachers' passionate affects performance.

Table 1: Teachers' Professionalism as Perceived by Heads of Schools

\begin{tabular}{llccc}
\hline SN & \multicolumn{1}{c}{ Item in the Questionnaire } & Mean & Std. Dev & Interpretation \\
\hline 1 & Good teacher pupil relationship influences performance & 4.71 & 0.765 & Strongly Agree \\
2 & Policy reform influences achievement & 3.92 & 1.035 & Agree \\
3 & Teachers monitor assignments given to pupils & 4.30 & 0.710 & Agree \\
4 & Co-curriculum activities affect achievement & 2.94 & 1.271 & Neutral \\
5 & Wastage of learning time affects achievement & 4.42 & 0.851 & Agree \\
6 & Teachers' prolonged absenteeism affects pupils' achievement & 4.67 & 0.644 & Strongly Agree \\
7 & Lack of teacher motivation affects performance & 4.35 & 0.717 & Agree \\
8 & Teachers' passionate about their work influences the achievement & 4.80 & 0.966 & Strongly Agree \\
\hline
\end{tabular}

Table 2: Pupils' Behavior

\begin{tabular}{llccc}
\hline SN & \multicolumn{1}{c}{ Item in the Questionnaire } & Mean & Std. Dev & Interpretation \\
\hline 1 & Pupils are independent, autonomous and self-driven & 2.97 & 1.212 & Neutral \\
2 & Pupils' absenteeism has affected achievement & 4.51 & 0.850 & Strongly Agree \\
3 & Pupils' negative attitude toward curriculum affect achievement & 4.20 & 1.034 & Agree \\
4 & Learners perform poorly due to involvement in out of class activities & 2.77 & 1.332 & Neutral \\
5 & Learners often disrupt the teaching and learning process & 3.09 & 1.434 & Neutral \\
\hline
\end{tabular}

This suggests that school heads considered teachers as important persons in determining the achievement of students. Therefore, for a school to excel, it requires teachers who are well motivated and have a great love for their work. It also requires teachers who are ready and willing to work beyond official working hours. Just like other professionals like medical doctors, teachers must be ready to give all they have to better the life of their clients.

The danger of teachers' prolonged absenteeism is shown by findings of previous studies by Kasuni (2011) and UNESCO (2005) which established that teachers' unprofessional behavior such as absenteeism and lack of commitment affect their reputation in the society. They further recommended that teachers as professionals should be committed to their calling as teachers. According to Huitt (1994), in schools where teachers are committed and passionate about their work, the pupils are bound to do very well as compared to schools where teachers do not care about any aspect of teachers' code of conduct such as time management. Therefore, teachers as professionals should be responsible, honest, dedicated and committed in their duties.

Through interview, heads of schools were asked to explain how the relationships between teachers and learners affect performance. The school heads indicated that their schools had a large number of pupils in class. Teachers were overworked to a point where they could not tolerate weak learners. This created a bad relationship between the two parties and therefore affected the teaching and learning quality. The school heads also pointed that large number of pupils in classes made marking of pupils' work difficult and therefore teachers could not monitor the pupils' performance as required by professional standards; large classes also affected teachers ability to control the class; it made it difficult for teachers to handle individual differences in classes. This experience tends to affect teachers' professionalism which in turn may affect the rates of students' academic achievement. Therefore, teachers as professional are expected to ensure that individual learners benefit from learning sessions as they prepare schemes of work, lesson plans and teach effectively.

\section{Pupils' Behavior}

As seen in table 2, the second objective sought to establish the perception of heads of schools regarding how pupils' behavior determined academic achievement.

According to Table 2, school teachers strongly agreed that pupils' absenteeism affects achievement. Learners who miss classes are likely not to benefit from the learning process and as 
result, the habit affects the achievement of the learners. The lack of continuous attendance may result into the learners missing some prerequisite knowledge which makes the subsequent topics not well understood. According to Wasanga, Ogle and Wambua (2010), pupils' absenteeism can have a major influence on pupils' academic achievement in that, pupils who miss classes cannot do well in their studies.

Furthermore, the results in table 2 also indicate that pupils' attitude towards the curricula was negative and therefore could be a contributing factor toward low achievement of the learners. The negative attitude toward the teaching and learning process reduces the interest toward learning and therefore, however much teachers devote their time in teaching effectively, learners' achievement may be affected by their lack of interest in the school curriculum. According to Wardlaw (2008), each teaching and learning session is a teamwork process which requires the contribution of teachers and pupils and each party must effectively contribute to the process.

Kutnick (1988) observes that pupil-teacher interaction plays a critical role in enhancing achievement in that when the two parts interact and each does their part effectively, learning effectiveness occur. Huitt (1994) further argued that one of the reasons some learners do better than others in school is because of differences in their behaviors. Those who value education and strive to master the content are more likely to succeed than those with negative attitude toward the curriculum and the leaning process. Finally, Jamah and Otieno (2011) observe that it is pupils who work hard and have life goals generated from the community and have a positive attitude towards the curriculum who are likely to succeed in their studies.

\section{Conclusions and Recommendations}

This section provides the conclusions and then gives the recommendations.

\section{Conclusions}

The study concludes that teachers' professionalism determines pupil's enhanced academic achievement while teachers' unprofessional behaviors such as absenteeism, lack of passion for work and wastage of learning time affects learning and therefore contribute toward poor academic achievement.

Secondly, it is concluded that Pupils' behaviors contribute toward the rate of their academic achievement as those learners who are committed toward learning and have positive attitude toward the school curriculum are more likely to attain higher achievement than those learners with negative attitude toward learning.

\section{Recommendations}

Based on the findings of this study, it is recommended that teachers need to maintain the professional standards and be committed to teach effectively for learners to realize the highest academic achievement. Likewise, learners need to be encouraged to develop positive attitude toward learning while attending school effectively as when the teacher and the learner do their part effectively, maximized learning outcomes are likely to take place. Therefore, teachers and parents should come up with strategies to help learners to develop positive attitude toward schooling and attend school regularly. These will contribute towards improved academic achievement in schools under investigation.

\section{Reference}

Abagi, O., and Odipo, S. (1997). Efficiency of primary education in Kenya: Situational analysis and implications for education reform (Discussion paper). Nairobi: Institute of Policy Analysis and Research.

Adesoji, F. A., \& Olatunbosun, S. M. (2008). Student, Teacher and School Environment Factors as Determinants of Achievement in Senior Secondary School Chemistry. Uluslararası Sosyal Ara_tırmalar Dergisi. The Journal of International Social Research, 1(2), Winter, 2008.

Aijaz, S. N. (2002). Learning Achievement in Primary Schools of Pakistan. A Quest for Quality Education. Islamabad: UNESCO.

Arends, R. (2011). Learning to Teach ( $9^{\text {th }}$ ed.). Boston: McGraw Hill.

Ayiro, L. P. (2011). Teacher Education and Management in the $21^{\text {st }}$ Century. Unpublished Paper Presented During Primary Teachers Colleges Principals Education Conference. Eldoret: Moi University.

Farrant, J. S. (2007). Principles and Practice of Education. Essex: Longman (reprint). 
Goyal, S. (2007). Learning achievement in India: A Study of Primary Education in Orissa. Washington: World Bank.

Huitt, W. (1994). The Teaching/Learning Process: A discussion of Models. Valdosta: Valdosta State University.

Jamah, A., \& Otieno, R. (2011, December 29). Long, hard road to honor and glory. The Standard, p. 3. Nairobi: SG.

Kasuni, J. S. (2011). Issues on School Management. Nairobi: Unpublished.

Kenya Institute of Education (2010). Summative Evaluation of the Primary School Education Curriculum. Retrieved April 20, 2011 from http:// www.kie.ac.ke.

Kibera, L. W., \& Kimokoti, A. (2007). Fundementals of Sociology of Education. Nairobi: Nairobi University.

Kumar, R. (2011). Research Methodology: A Step by Step Guide for Beginners. London: SAGE.

Kutnick, P. S. (1988). Relationships in the primary school classroom. Manchester. Paul Chapman.

Ministry of Education (2003). Report of the Sector Review and Development. Nairobi: Ministry of Education.

Mulkeen, A and Chen, D. (Eds.). (2008). Teachers for rural schools. Washington: World Bank.

Musvosvi, D. (1998). Alternative Approach to Educational Administration. Kendu Bay: Africa Herald.

Oduor, A. (2011, Dec. 29). Counties ranked, repeating banned. The Standard, p. 1. NBI: SG.

Oluka, S., \& Okurut, C. (2008). Performance in primary education in the Teso region: an exploratory study. Nairobi: UNESCO. http://www.unescouganda.ug/index.php?op tion=com docman\&task=cat view\&gid=48\&l temid $=8$.

Onyango, D. O. (2008). Implementation of the PreSchool Curriculum in Kenya: $A$ Case of Changamwe Division Mombasa District
(Unpublished M.Ed thesis). University of Eastern Africa, Baraton.

Orido, (2011, Dec. 29). Candidates get smarter at cheating. The Standard, p. 9. Nairobi: SG.

Ornestein, A. C., \& Hunkins, F. P. (1998). Curriculum: Foundations, Principles, and Issues ( $3^{\text {rd }}$ ed). Allyn and Bacon, Needham Heights.

Otieno, S. (2010). KCPE: "The Curse" of free Education. The Standard, p.1. Nairobi: SG.

Otunga, R.N and Nyandusi C. (2011). The context of curriculum Development in Kenya. Eldoret Moi University. Retrieved November 11, 2011 from http:www.moi university.ac.ke.

Reche, G. N., Bundi, K. T., Riungu, J. N., \& Mbugua, Z. K. (2012). Factors contributing to poor performance in Kenya Certificate of Primary Education in Public Day Primary Schools in Mwimbi Division, Maara District, Kenya. Retrieved April 23, 2013 from Http//www.ijhssnet.com.or/ER.

Tanner, D., \& Tanner, L. (1995). Curriculum Development Theory and practice ( $3^{\text {rd }}$ ed.). Eagle wood cliffs: Meril, an Imprint of Prentice Hall Inc.

Ubogu, R. E. (2004). The causes of Absenteeism and Dropout among Secondary school students in Delta state (Unpublished Ph.D Thesis). Delta State University. Retrieved April 19, 2013

from http://www.academicjournals.org.

UNESCO (2005). Challenges of Implementing Free Primary Education in Kenya: An Assessment Report. Paris: UNESCO.

Wardlaw, C. (2008). Curriculum Delivery. Unpublished Paper Presented During Curriculum Corporation Conference. Melbourne: Curriculum Corporation.

Wasanga, P. M., Ogle, M. A., \& Wambua, R. M. (2011). The Report on Monitoring Learner Achievement Study for Class 3 in Literacy and Numeracy. Nairobi: Kenya National Examinations Council. Retrieved October 15, 2011 from http://www.Knec.ac.ke.

Wiles, J., \& Bondi, S. (2011). Supervision: A Guide to Practice $\left(4^{\text {th }}\right.$ ed.). Columbus: Prentice Hall. 